\title{
Potential Areas for Commercial Timber Plantations of Tabebuia rosea (Bertol.) DC. in Michoacan, Mexico
}

\author{
Hipolito Jesús Muñoz-Flores ${ }^{1}$, David Castillo-Quiroz ${ }^{2}$, Francisco Castillo-Reyes ${ }^{2}$, \\ J. Trinidad Sáenz-Reyes', Diana Avila-Flores², Agustín Rueda-Sánchez ${ }^{1}$
}

${ }^{1}$ National Institute of Forestry, Agriculture and Livestock Research (INIFAP)-Experimental Station Uruapan, Uruapan, México

${ }^{2}$ National Institute of Forestry, Agriculture and Livestock Research (INIFAP)-Experimental Station Saltillo, Saltillo, México

Email: castillo.david@inifap.gob.mx

How to cite this paper: Muñoz-Flores, H. J., Castillo-Quiroz, D., Castillo-Reyes, F., SáenzReyes, J. T., Avila-Flores, D., \& RuedaSánchez, A. (2017). Potential Areas for Commercial Timber Plantations of Tabebuia rosea (Bertol.) DC. in Michoacan, Mexico. Open Journal of Forestry, 7, 48-57. http://dx.doi.org/10.4236/ojf.2017.71004

Received: November 24, 2016 Accepted: December 25, 2016 Published: December 28, 2016

Copyright $\odot 2017$ by authors and Scientific Research Publishing Inc. This work is licensed under the Creative Commons Attribution International License (CC BY 4.0).

http://creativecommons.org/licenses/by/4.0/

(c) (i) Open Access

\begin{abstract}
The targeted area for plant reforestation in the state of Michoacan is made up of eroded areas and pasture induced areas, both adding to 525,260 ha and representing $10.9 \%$ of the total surface of the state. The regions with the largest areas in need of reforestation are the Costa with 185,396 ha (29\%), Oriente with 106,836 (17\%) and Tierra Caliente with 96,284 (15\%). Commercial forest plantations are an alternative for reducing the pressure on natural forests and creating options for sustainable and diversified development, changing the land use from fragmented agriculture and livestock purposes to forestry. The object of this study was to determine potential areas for the establishment of commercial forest plantations of Tabebuia rosea (Bertol.) DC. in the state of Michoacan, Mexico, by using geographic information systems. The outlining of potential areas was performed with the IDRISI 32 and ArcView programs, according to the environmental requirements of $T$. rosea. These environmental requirements include precipitation, temperature, soil, altitude, land use and slope. The analysis resulted in two maps where the potential areas for the establishment of commercial forest plantations with this species were shown, which turned out a total potential area of 54,320 ha, distributed in 47,566 ha considering a slope of $0 \%-15 \%$ for non-manual forest plantations, and 6754 ha considering a slope of $15 \%-30 \%$ for manual forest plantations. The ecologic conditions in Michoacan are favorable for successful establishment and development of commercial forest plantations of $T$. rosea.
\end{abstract}

\section{Keywords}

Potential Areas, Michoacan, Commercial Forest Plantations, Tabebuia rosea, Geographic Information System 


\section{Introduction}

Currently, the state of Michoacan in Mexico is characterized by a considerably deforested area of nearly 525,260 ha, resulting in an annual loss of 52,526 hectares. According to the Forest and Soil Inventory from 2014 of the State, the eroded areas and the induced pasture areas represent the $10.9 \%$ of the total land surface of the state (COFOM, 2014).

An alternative for reducing the damage due to anthropological activities in natural forests is the establishment of commercial forest plantations, which would help reduce the pressure on natural forests and create strategies for sustainable development. Commercial plantations as productive diversification activities will help to convert that fragmented agricultural soil into forest areas. However, this activity should be carefully planned. In this regard, there have been studies conducted in the state of Michoacan on commercial forest plantations, analyzing the ecosystem's cold temperature climate with $68 \%$ of the forest species corresponding to Pinus genus, the tropical climate, where $24 \%$ of the species are exotic, such as Tectona grandis L.F. and Acrocarpus fraxinifolius Arn., and the remaining $8 \%$ are Eucalyptus camaldulensis Dehnh. and native species such as Caesalpinia platyloba (S. Watson), Tabebuia rosea (Bertol.) DC., Roseodendron donnell-smithii (Rose) Miranda and Leucaena leucocephala (Lam.) de Wit (COFOM, 2003).

During the last 15 years, several studies have been performed in Mexico concerning the productive potential of certain plant species in temperate and tropical forests, as well as in arid and semi-arid land ecosystems using Geographic Information Systems (GIS). In the literature reporting the findings of the GIS applications for site selection, we include the potential areas for plantation of conifers such as Abies religiosa (Kunth) Schltdl. \& Cham., Pinus pseudostrobus Lind., P. michoacana, P. montezumae, P. teocote, $P$. oocarpa, $P$. ayacahuite, P. lawsonii, and P. herrerae, in Michoacan (Saenz et al., 2000). Rueda et al., 2006 generated maps of potential areas for forest plantations of 11 species of the genus Pinus in Jalisco. Muñoz et al., 2016 generated maps of the potential areas for commercial timber plantations of Enterolobium cyclocarpum (Jacq.) Griseb. in Michoacan. In another study, Rueda et al. (2007) generated maps showing the productive potential for six tropical species in this same state. Díaz (2007) conducted a study to determine the potential areas for plantations of Pinus montezumae Gordon \& Glend., P. patula, P. cembroides, Pseudotsuga menziesii (Mirb. Franco), Juniperus deppeana Steud. Also Saenz et al. (2007-2011) in their study identified potential areas for commercial forest plantation and silvopastoral systems in the basin of Lake Cuitzeo in Michoacan. In arid and semi-arid ecosystems, Castillo et al., 2014 conducted a study to identify potential areas for the establishment of plantations of Agave lechuguilla Torr. Martinez and Castillo (2007) conducted a study for selecting sites for planting Nolina cespitifera Trel. Meza (2003) identified potential areas for the establishment of plantations of Turnera diffusa Wild.

In this article we propose the planting of Tabebuia rosea (Bertol.) DC. Bignoniaceae (Tropicos, 2016). T. rosea is a species that in Mexico is known by various common names depending on the region or state where it is spread out. Specifically, in the state of Michoacan, it is known as roble (oak) (Muñoz et al., 2012). The growth of this spe- 
cies is very variable, and depends on the quality of the forest site, age, planting density and management. Trees planted in places with good weather conditions can grow up to 3.0 meters high in the first year. In southeast Mexico, T. rosea can attain an annual growth in height ranging from 1.5 to $2.0 \mathrm{~m}$ and 1.5 to $2.0 \mathrm{~cm}$ in diameter, from which a wood volume production of 10 to $20 \mathrm{~m}^{3} / \mathrm{ha} /$ year, and an increase from 15 to 25 $\mathrm{m}^{3} / \mathrm{ha}$ /year can be obtained (Webb et al., 1980; Geilfus, 1989; Manzanilla et al., 2001). The wood obtained from $T$. rosea is used for interior decoration, for furniture manufacturing, cabinet wheels for carts, crafts, agricultural equipment and musical instruments. The thin wood, branches and waste can be used for firewood or charcoal. It is also a species classified among melliferous plants (Webb, 1980; Niembro, 1992; Herrera and Lanuza 1995; Manzanilla et al., 2001; CNIC, 2005).

Currently natural populations of $T$. rosea have decreased considerably due to anthropogenic activities, mostly deforestation for the building of human settlements combined with the obtainment of wood, contributing to the reduction of their habitat. The objective of this study was to determine the potential areas for commercial forest plantations of Tabebuia rosea (Bertol.) DC. in the State of Michoacan, Mexico, through the use of Geographic Information Systems.

\section{Materials and Methods}

\subsection{Study Area}

Figure 1 shows the study area corresponding to the state of Michoacan, which is located to the West of Mexico. The specific coordinates are from $100^{\circ} 04^{\prime} 45^{\prime \prime} \mathrm{W}$ to $103^{\circ} 44^{\prime} 49^{\prime \prime} \mathrm{W}$, and from $20^{\circ} 23^{\prime} 43^{\prime \prime} \mathrm{N}$ to $18^{\circ} 09^{\prime} 47^{\prime \prime} \mathrm{N}$. The territory of Michoacan spreads

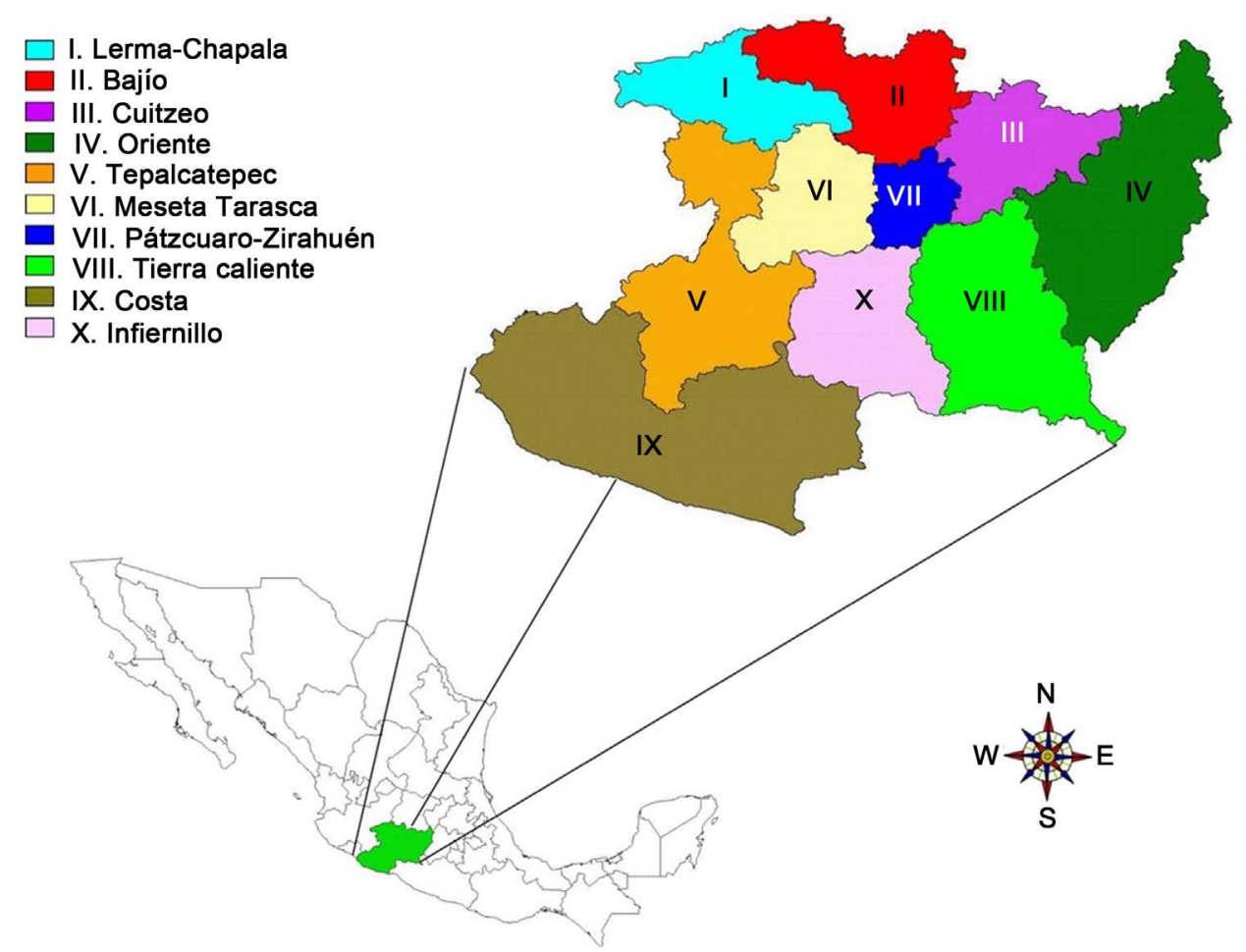

Figure 1. Geographic location of Michoacan, the study area. 
out through an area of $59,864 \mathrm{~km}^{2}$, and it is located to the Northwest of Guerrero, North of the Pacific Ocean, South from Guanajuato and Querétaro, and to the East of Colima and Jalisco. Michoacan's administration is divided into 113 municipalities. (COFOM, 2014; INEGI, 2012).

The climate in Michoacan is affected by one main geographic factor: the changes in elevation caused by its topography. Michoacan is characterized by a series of mountain ranges parallel to the coastline. Climate patterns tend to be predominantly sub-humid (54.5\%) on the Pacific coast plains and Sierra Madre del Sur, 29\% tempered subhumid in the Trans-Mexican Volcanic Axis, 15\% dry and semi-dry in the lower and middle parts of the depression of Balsas and Tepelcatepec, $1 \%$ tempered wet and $0.5 \%$ warm wet, and tempered subhumid in the high regions of Trans-Mexican Volcanic Axis. The average annual temperature is $20^{\circ} \mathrm{C}$, with a sharply dry winter season, the lowest temperatures, around $8^{\circ} \mathrm{C}$, occur in the month of January. The maximum high temperature averages $31^{\circ} \mathrm{C}$ and occurs in the months of April and May; the average precipitation in the state is $850 \mathrm{~mm}$ annually, where rains occur during the summer in the months of June to September. The predominant soil type in the state is the result of volcanic ash (Andosols). These soils are found at Eje Neovolcánico and Sierra Madre del Sur. In this edaphic province, Vertisols also appear in mountain ranges and valleys. On hills and mountains, Leptosols, Luvisols, and Feozems types might be present. Andosols dominate the Meseta Tarasca. Soil types in Sierra Mil Cumbres, at high elevation sites, are also Andosols. Acrisols and Luvisols are found at piedmonts, creeks and valleys. Feozems normally can be seen at the edge of crop lands. Low lands and flat ground places with non-irrigated and irrigated agriculture, or natural vegetation of subtropical woodlands and grasslands tend to be Vertisols. Leptosols are distributed in random patterns throughout steep terrain and rocky outcrops (Muñoz et al., 2016).

\section{Subdivision of the Study Area}

Michoacan state is divided in 113 counties, which for this study purposes was subdivided in ten regions, defined according the regionalization of the Forestry Commission of state of Michoacan (COFOM, 2014) (Table 1).

Table 1. Municipalities and Michoacan forest regions, according to the Forestry Commission of the State of Michoacan (COFOM, 2014).

\begin{tabular}{lr}
\hline \multicolumn{1}{c}{ Region } & Municipalities \\
\hline $\begin{array}{l}\text { I. Lerma-Chapala } \\
\text { II. Bajío }\end{array}$ & $\begin{array}{r}\text { Triseñas, Chavinda, Cojumatlán, Ixtlán, Jacona, Jiquilpan, Marcos Castellanos, Pajacuarán, Purépero, Sahuayo, } \\
\text { Angamacutiro, Coeneo, Churintzio, Ecuandureo, Huaniqueo, Jiménez, José Sixto Verduzco, Morelos, } \\
\text { Numarán, Penjamillo, La Piedad, Paníndicuaro, Puruándiro, Tanhuato, Yurécuaro, Zináparo, Zacapu. }\end{array}$ \\
III. Cuitzeo & $\begin{array}{c}\text { Acuitzio, Álvaro Obregón, Copándaro, Cuitzeo, Charo, Chucándiro, Huandacareo, } \\
\text { Indaparapeo, Morelia, Queréndaro, Santa Ana Maya, Tarímbaro, Zinapécuaro. }\end{array}$ \\
IV. Oriente & $\begin{array}{r}\text { Angangeo, Aporo, Contepec, Epitacio Huerta, Hidalgo, Irimbo, Juárez, Jungapeo, Maravatío, } \\
\text { Ocampo, Senguio, Susupuato, Tlalpujahua, Tuxpan, Tuzantla, Tiquicheo, Tzitzio, Zitácuaro. }\end{array}$ \\
V. Tepalcatepec & Charapan, Cherán, Chilchota, Nahuatzen, Nuevo Parangaricutiro, Paracho, \\
VI. MesetaTarasca & Tancítaro, Taretan, Tingambato, Uruapan, Ziracuaretiro. \\
VII. Pátzcuaro-Zirahuén \\
VIII. Tierra Caliente \\
$\begin{array}{l}\text { IX. Costa } \\
\text { X. Infiernillo }\end{array}$ \\
Erongarícuaro, Huiramba, Lagunillas, Pátzcuaro, Quiroga, Salvador Escalante, Tzintzuntzan. \\
Parácuaro, Huetamo, Madero, Nocupétaro, San Lucas, Tacámbaro, Turicato. \\
Aquila, Arteaga, Coahuayana, Coalcomán, Chinicuila, Lázaro Cárdenas, Tumbiscatío. \\
Ario de Rosales, Churumuco, La Huacana, Gabriel Zamora, Múgica, Nuevo Urecho.
\end{tabular}




\subsection{Natural Distribution and Environmental Requirements to Determine Potential Areas of Tabebuia rosea (Bertol.) DC.}

This species is spread out from southern México to Central America and Venezuela and Ecuador. It has been found growing from sea level to $1200 \mathrm{~m}$, in temperatures ranging from $20^{\circ} \mathrm{C}$ to $30^{\circ} \mathrm{C}$, with annual rainfall over $500 \mathrm{~mm}$. Grows associated to various types of vegetation: tropical forest evergreen, semi-deciduous tropical forest and tropical deciduous forest (Niembro, 1992) as well as disturbed vegetation, and usually grows in areas with a high degree of disturbance. In Mexico, it is located on the coastal plains of the Gulf of Mexico, from southern Tamaulipas, northern Veracruz and Puebla, from northern Chiapas to southern Quintana Roo; in the Pacific coastal plains it spreads out from Nayarit to Chiapas, including Michoacan.

The criteria considered relevant to the growth of $T$. rosea involve climate, soil and topography aspects. These criteria were obtained through the review of literature, particularly the works of Webb (1980), Webb et al. (1980), Niembro (1992), Geilfus (1989), Rural Development Secretary (SEDER) (1995), Martinez (1997), Pennington \& Sarukhán (1998) and CNIC (2005). The information was obtained generally for dry tropical conditions in the state of Michoacan; once the information was systemized, we went on to determine the requirements for this species. The search scheme for potential areas chose sites meeting the following environmental features for $T$. rosea were elevation, total annual rainfall, annual average temperature, soil type and slope (Table 2).

\subsection{Determining Areas of Potential Maps}

IDRISI 32 (2.0) (Eastman, 1999) software was used to produce maps and estimates of area with potential for commercial forest plantations of Tabebuia rosea (Bertol.) DC. IDRISI is one of many commercial software products that handle Geographical Information Systems (GIS) databases, as well as charts, imagery and climate digital information from National Institute of Forestry, Agriculture and Livestock Research were used. The Digital Elevation Model (DEM) employed had a $360 \mathrm{~m} \times 360 \mathrm{~m}$ resolution, equivalent to $12.96 \mathrm{ha}$, that is, each pixel (cell) covers this area; all variables were measured within this spatial frame. Screening sorted sites using RECLASS command. A hierarchical screening sequence was designed for this purpose, according to the following categories or fitness classes: Unsuitable $=0$ Sites lacking required ecological features for growth and development of the studied taxon. Suitable $=1$ Sites that offer the required ecological features for a certain species.

Table 2. Environmental requirements considered to assess sites potentially suitable for commercial forest plantations of Tabebuia rosea (Bertol.) DC. in Michoacan, Mexico.

\begin{tabular}{cc}
\hline Environmental requirement & Optimal requirement \\
\hline Elevation (masl) & $0-1000$ \\
Annual rainfall $(\mathrm{mm})$ & $700-1000$ \\
Annual average temperature $\left({ }^{\circ} \mathrm{C}\right)$ & $20-27$ \\
Soil type & Vertisol and Pantosol \\
Slope & $0 \%-15 \%$ and $15 \%-30 \%$ \\
\hline
\end{tabular}


GIS thematic layers displayed each variable and its range of values spread throughout the geographic distribution range of $T$. rosea. These layers were then joined through Overlay command. The resulting product represents the potential areas in RASTER format. Command AREA produced a quantitative estimate of potential area. IDRISI command Reformat was used to convert to vectorial format, and then exporting it to Shape file for further work on ARCVIEW 3.2. GIS software for rendering 1:100,000 and 1:250,000 scale outputs.

\subsection{Validation of Potential Areas}

The sites outlined in the maps showing the potential zones for the studied species were visited in the field to assess the presence of suitable ecological conditions that favor the establishment and development of $T$. rosea plantations, also considered suitable for commercial forest plantations, chosen randomly and geo-referenced by accurate data in the selected areas.

\section{Results and Discussion}

According to the methodology and analysis used for environmental requirements, elevation, total annual precipitation, mean annual temperature, slope, land use, and soil type in GIS, two maps were generated showing the sites with potential areas for developing plantations with $T$. rosea. Two site slope classes were selected, one with slope between $0 \%$ and $15 \%$ for mechanized plantations. The other site class was selected in the $15 \%$ to $30 \%$ slope range, assuming manual planting for these conditions.

\subsection{Maps Potential Areas for Tabebuia rosea (Bertol.) DC.}

Two maps where potential areas are shown for the establishment of commercial forest plantations of $T$. rosea were generated, considering two slope type sites, one with a slope from $0 \%$ to $15 \%$ for mechanized plantations. This case refers to plantation sites that can be irrigated and rainfall conditions for agriculture are possible, and therefore site preparation for forest plantation and timber harvest operations can be mechanized. The other slope type site selected was from $15 \%$ to $30 \%$, allocating manual planting for these conditions.

Areas suitable for mechanized establishment (slope $0 \%$ to 15\%) for commercial plantations of $T$. rosea were found in five forest regions of Michoacan: IV Oriente (12 ha), V Tepalcatepec (18,862 ha), VI Meseta Purépecha (129 ha), IX Costa (8223 ha) y X Infiernillo (20,340 ha), which add up to 47,566 ha (Figure 2).

Areas suitable for forest plantations, whether non-mechanized or manual (15\% - 30\% slope) of $T$. rosea they add up to $6754 \mathrm{ha}$, located in the same regions of the state, with slopes from 15\% to 30\%: IV Oriente (51 ha), V Tepalcatepec (3,667 ha), VI Meseta Purépecha (116 ha), IX Costa (1429 ha) y X Infiernillo (1491 ha) (Figure 3).

For the particular case of Region X Infiernillo, V (Tepalcatepec) and IX (Costa) they account to $20,324,18,862$ and 8223 ha, respectively, with mechanized plantation potential and, which are characterized by a tropical climate with clay soil and annual rainfall of 700 to $1000 \mathrm{~mm}$, altitudinal gradient lower than 1,000 meters above sea level. For the region VI (Meseta Purépecha) the potential areas were 116 ha and are distributed in 


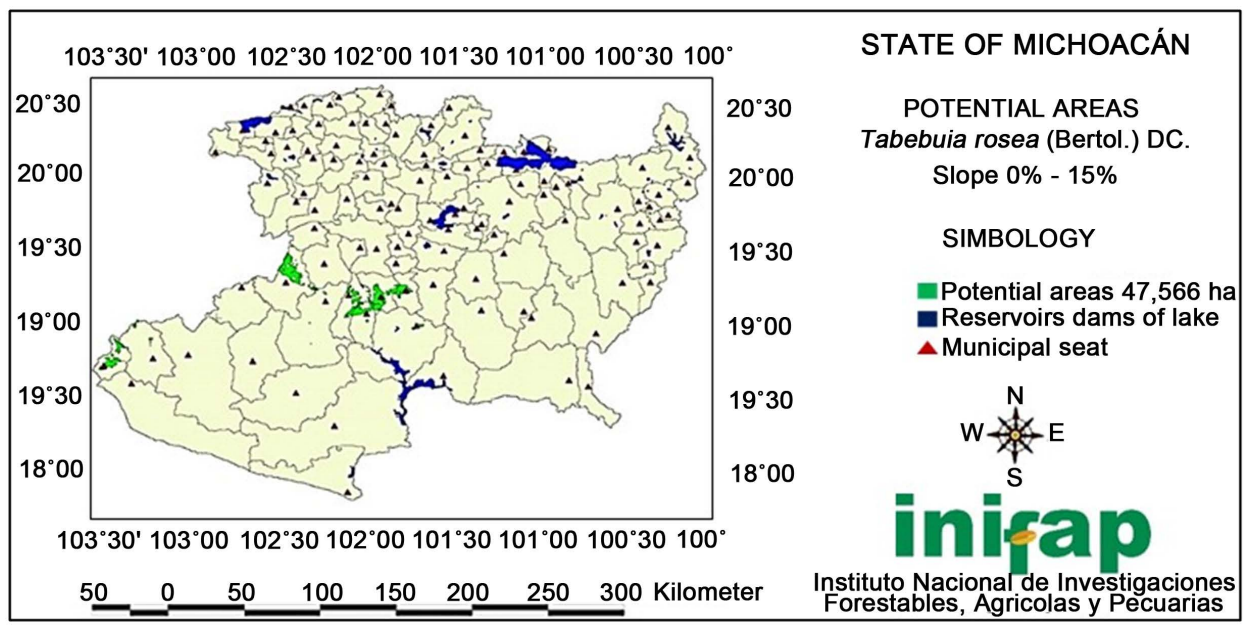

Figure 2. Areas with potential for mechanized establishment of commercial plantations of Tabebuia rosea (Bertol.) DC., in Michoacan, Mexico (slope 0 to 15\%).

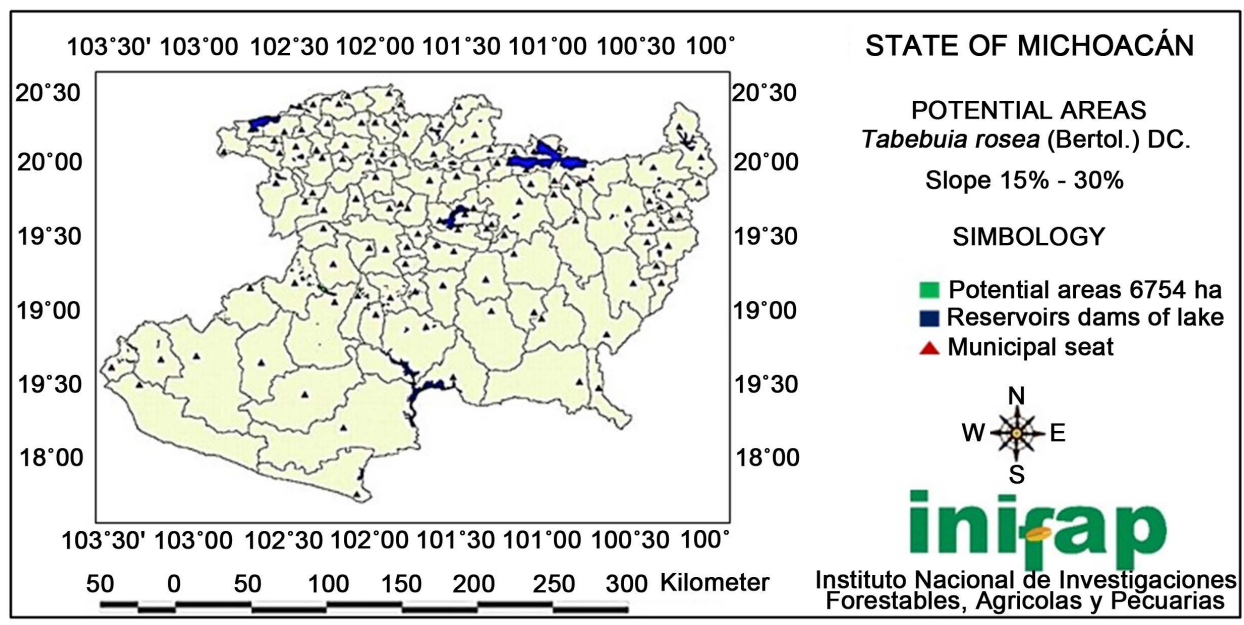

Figure 3. Area with potential for non-mechanized establishment of commercial plantations of Tabebuia rosea (Bertol.) DC. in Michoacan, Mexico (slope 15\% to 30\%).

Taretán and Ziracuaretiro, which have similar climate and soil conditions as Region IV.

The productive potential for commercial plantations with T. rosea in Michoacan was of 54,320 ha, distributed among main regions $\mathrm{V}$ and $\mathrm{X}$ (Tepalcatepec and Infiernillo), respectively. These two regions represent a total surface of 44,360 ha. Characterized by an altitudinal range lower than $1000 \mathrm{~m}$, a lower limit than the one cited by Webb, 1980; Geilfus, 1989; Martinez, 1997; CNIC, 2005.

These results are similar to those reported by Rueda et al., 2006 and Rueda et al., 2007 who used the same variables as those of this work and generating maps of potential areas for forest plantations of 11 pine species and six tropical species for the state of Jalisco. It also matches Saenz et al. (2000) which was performed in the eastern region of Michoacan for the identification of potential areas for the plantation of Abies religiosa (Kunth) Schltdl. \& Cham., P. pseudostrobus, P. michoacana, P. montezumae, P. teocote, $P$. oocarpa, $P$. ayacahuite, $P$. lawsonii and $P$. herrerae, and Muñoz et al., 2016 generated maps of the potential areas for commercial timber plantations of Enterolobium cyclocarpum (Jacq.) Griseb. in Michoacan using the same climate variables. 
Similarly, our results coincide with Saenz et al. (2007, 2011) which reporting the identifying of potential areas for the commercial forest plantation and silvopastoral systems in the Cuitzeo Lake basin in Michoacan. In addition, are consistent with Meza (2003) in their study for locate potential areas for the establishment of plantations Turnera diffusa Willd. and INIFAP in your diagnosis to determine potential areas in the state of Michoacan, considering virtually the same variables (altitude, rainfall, the average annual temperature, slope, uses and soil type, and using the same GIS procedure. Díaz (2007) in his study of agricultural production potential of forest species in Mexico considered virtually the same variables.

Likewise, our results agree with Saenz et al. $(2007,2011)$ which reported the identification of potential areas for the commercial forest plantation in silvopastoral systems of the Cuitzeo Lake basin of Michoacan. In addition, they are consistent with Meza (2003) in their study to locate potential areas for the establishment of plantations of Turnera diffusa Willd. and INIFAP in their findings to determine potential areas in the state of Michoacan, considering virtually the same variables (altitude, rainfall, the average annual temperature, slope, uses and soil type, and using the same GIS procedure as Díaz (2007) in his study of agricultural production potential of forest species in Mexico.

\subsection{Validation of Potential Areas}

Table 3 and Table 4 are shown the geographical location and climate characteristics associated with the verification sites, carried out in order to corroborate that the area delimited and deemed with potential for planting $T$. rosea is within the characteristics outlined and analyzed by the database, according to the environmental requirements of the species, with the purpose of guaranteeing the reliability of the maps generated showing the potential areas for commercial plantations. The sites outlined shown in the maps and the results obtained from the verification sites indicate that the areas delimited in the maps meet the conditions for the establishment of commercial forest plantations of $T$. rosea in the state of Michoacan.

Table 3. Geographic location of sampling sites for the validation of potential areas for commercial forest plantations of Tabebuia rosea (Bertol.) DC. in the state of Michoacan.

\begin{tabular}{|c|c|c|c|c|}
\hline No Sites & Locality & Municipality & Latitude N & Longitude W \\
\hline 1 & El Mirador & Nuevo Urecho & $19^{\circ} 11^{\prime} 40^{\prime \prime}$ & $101^{\circ} 51^{\prime} 53.8^{\prime \prime}$ \\
\hline 2 & Rancho La Guadalupe & Nuevo Urecho & $19^{\circ} 12^{\prime} 38^{\prime \prime}$ & $101^{\circ} 53^{\prime} 07^{\prime \prime}$ \\
\hline
\end{tabular}

Table 4. Agroecological characterization of sampling sites for the validation of potential areas for commercial forest plantations of Tabebuia rosea (Bertol.) DC. in the state of Michoacan.

\begin{tabular}{ccccccc}
\hline No Sites & Climate & Soil types & Slope (\%) & $\begin{array}{c}\text { Elevation } \\
\text { (masl) }\end{array}$ & $\begin{array}{c}\text { Annual } \\
\text { rainfall } \\
\text { mm }\end{array}$ & $\begin{array}{c}\text { Annual } \\
\text { average } \\
\text { temperature }\left({ }^{\circ} \mathrm{C}\right)\end{array}$ \\
\hline 1 & Tropical & Vertisol & $15-30$ & 625 & 759 & 26.4 \\
2 & Tropical & Vertisol & $0-15$ & 514 & 747 & 25.6 \\
\hline
\end{tabular}




\section{Conclusion}

The ecologic conditions in Michoacan are favorable for successful establishment and development of commercial forest plantations of Tabebuia rosea (Bertol.) DC. Areas suitable for mechanized establishment of commercial plantations of $T$. rosea add up to 47,566 ha and manuals plantations were 6754 ha. Locating specifically in V Tepalcatepec, IX Costa and X Infiernillo, results have provided support to decisions on land use planning and establishment of commercial forest plantations of T. rosea in Michoacan. Geographic information systems are dependable tools in assessing the potential sites for growing of $T$. rosea.

\section{References}

Castillo-Quiroz, D., Martínez-Burciaga, O. U., Avila-Flores, D. Y., Castillo-Reyes, F., \& Sánchez-Chaparro, J. D. (2014). Identification of Potential Areas for Establishment of Plantations of Agave lechuguilla Torr. in Coahuila, Mexico. Open Journal of Forestry, 4, 520-526. https://doi.org/10.4236/ojf.2014.45056

Díaz, G. (2007). Agro-Production Potential of Forest Species in Mexico. In R. Fernández, C. Ortiz, M. Reyes, F. de J. Legorreta P. \& G. Garcia (Eds.), García Annual Research and Technological Innovation Report (p. 304). México: INIFAP. (In Spanish)

Eastman, J. R. (1999). IDRISI32 2.0: Guide to GIS and Image Processing. Worcester, MA: Clark Labs, Clark University.

Forestry Commission of State of Michoacan (COFOM) (2003). Forest Plantation Program of Michoacan. Revista Bosques y Selvas de Michoacan, 1, 6-7. (In Spanish)

Forestry Commission of state of Michoacan (COFOM) (2014). State Forest and Soil Inventory of Michoacan of Ocampo (Vol. 1, No. 1, p. 376). Morelia. (In Spanish)

Geilfus, F. (1989). The Tree at the Service of the Farmer. Manual for Agroforestry Rural Development. Vol 2, Species Guide, Santo Domingo. Enda-Caribe y CATIE, p. 377. (In Spanish)

Herrera, A. Z., \& Lanuza, R. (1995). Species for Reforestation in Nicaragua (p. 185). Managua: National Forest Service. (In Spanish)

https://www.yumpu.com/es/document/view/15450777/arboles-encontrados-en-zonas-cafetaler as-eco-index

Manzanilla, B. H., Martínez, D. M., \& Martínez, M. A. (2001). Monographs of Promising Native Species for the Establishment for Commercial Timber Plantations in Jalisco, Cedar and Purple Rose (pp. 51-73). Guadalajara: FIPRODEFO. (In Spanish)

Martinez, B. O. U., \& Castillo, Q. D. (2007). Identification of Sites for Plantations Cortadillo (Nolina cespitifera Trel.) in Southeast Coahuila (p. 38). Saltillo: CIRNE-INIFAP. (In Spanish)

Martinez, D. M. (1997). Silvicultural Guide of Tabebuia rosea (Bertol.) DC. (Rosa Morada): Forest Tree and Use Multiple in Mexico. In M. A. Musalem (Ed.), Silvicultural Guide of Tree Species of Multiple in Mexico (p. 250). Chapingo: Agroforestry Program for Sustainable Development, Universidad Autónoma Chapingo, Notes for the MSc Course. (In Spanish)

Meza, S. R. (2003). Identification Potential Area for Damiana Plantation in Baja California Sur (p. 28). Technical Bulletin No. 2, Baja California, Campo Experiential Todos Los Santos: NOROESTE-INIFAP. (In Spanish)

Muñoz, F. H. J., Sáenz, R. J. T., \& Rueda, S. A. (2012). Monography Forest Species for Commercial Plantations in Michoacan Tropical Climate (pp. 64-77). Technical Books No. 15, Michoacan: SAGARPA-INIFAP-CIRPAC-Urupan Experimental Field. (In Spanish)

Muñoz-Flores, H. J., Sáenz-Reyes, J. T., Rueda-Sánchez, A., Castillo-Quiroz, D., Castillo-Reyes, F., \& Avila-Flores, D. Y. (2016). Areas with Potential for Commercial Timber Plantations of 
Enterolobium cyclocarpum (Jacq.) Griseb. in Michoacan, Mexico. Open Journal of Forestry, 6, 476-485.

National Center of Coffee Research (CNIC) (2005). Tree Associated to Coffee Plantations (p. 149).

National Institute of Statistic and Geography (Mexico) (INEGI) (2012). Statistical Perspectives of Michoacan of Ocampo (p. 97). Aguascalientes: INEGI. (In Spanish)

Niembro, R. A. (1992). Trees and Shrubs of Mexico and Use (p. 206). México: LIMUSA. (In Spanish)

Pennington, T. D., \& Sarukhán, K. J. (1998). Tropical tree from Mexico. Fondo de Cultura Económica (2nd ed., pp. 138-139). México: UNAM-Fondo de Cultura Económica. (In Spanish)

Rueda, S. A., Ruiz, C. J. A., Flores, G. J. G., \& Talavera, Z. E. (2006). Productive Potential for 11 Species of Pine in Jalisco (p. 175). Technical Books No. 1, Guadalajara: Campo Experimental Centro Altos de Jalisco, CIRPAC, INIFAP. (In Spanish)

Rueda, S. A., Ruiz, J. A., Benavides, S. J. D., \& Flores, G. J. G. (2007). Definition of Favorable Areas for Six Tropical Forest Species in the State of Jalisco (p. 165). Technical Books No. 5, Tepatitlán de Morelos: SAGARPA-CIRPAC-INIFAP. (In Spanish)

Rural Development Secretary (SEDER) (1995). Main Features of Some Forest Species Susceptible to Commercial Use in the State of Jalisco (p. 32). Guadalajara: Integral Forestry Development Program of Jalisco State. (In Spanish)

Saenz, R. J. T., Chávez, L. G., García, M. J., \& Anguiano, C. J. (2000). Regionalization from Potential Areas for Forest Plantations in the East Region from Michoacan (p. 6). Montecillo: Natural Resource Subsecretary, General Direction of Forestry National Program, Ministry of the Environment, Natural Resources and Fisheries, College of Postgraduates. (In Spanish)

Saenz, R. J. T., Anguiano, C. J., Muñoz, F. H. J., Villaseñor, R. F. J., Rueda, S. A., \& García, M. J. J. (2007). Potential Areas for Commercial Forest Plantations in the Lake Cuitzeo Basin, Michoacan (p. 29). (In Spanish)

Saenz, R. J. T., Jiménez, O. J., Rueda, S. A., Ibáñez, R. C., \& García, M. J .J. (2011). Regionalization of Potential Areas for Silvopastoral Systems in Temperate Forest of Michoacan (p. 42). Technical Bulletin No. 23, Uruapan: SAGARPA-INIFAP-CIRPAC, Campo Experimental Uruapan. (In Spanish)

Tropicos (2016). Missouri Botanical Garden. http://www.tropicos.org/

Webb, D. B. (1980). Guide and Key for Selection of Species in Forest Trials from Tropical and Subtropical Region Development Administration London, England (p. 275). (In Spanish)

Webb, D. B., Wood, D. J., \& Smith, J. (1980). A Guide to Species Selection for Tropical and Subtropical Plantation (p. 342). Tropical Forestry Papers No. 15, Department of Forestry, Commonwealth Forestry Institute, Oxford: University of Oxford. 
Submit or recommend next manuscript to SCIRP and we will provide best service for you:

Accepting pre-submission inquiries through Email, Facebook, LinkedIn, Twitter, etc. A wide selection of journals (inclusive of 9 subjects, more than 200 journals) Providing 24-hour high-quality service

User-friendly online submission system

Fair and swift peer-review system

Efficient typesetting and proofreading procedure

Display of the result of downloads and visits, as well as the number of cited articles Maximum dissemination of your research work

Submit your manuscript at: http://papersubmission.scirp.org/

Or contact ojf@scirp.org 